\title{
An Ecological Basis for Managing Giant Sequoia Ecosystems
}

DOUGLAS D. PIIRTO

Natural Resources Management Department

California Polytechnic State University

San Luis Obispo, CA 93407, USA

ROBERT R. ROGERS

USDA Forest Service

Sequoia National Forest

900 West Grand Avenue

Porterville, CA 93257-2035, USA

ABSTRACT / A strategy for management of giant sequoia groves is formulated using a conceptual framework for eco- system management recently developed by Region Five of the USDA Forest Service. The framework includes physical, biological, and social dimensions. Environmental indicators and reference variability for key ecosystem elements are discussed in this paper. The selected ecosystem elements include: 1) attitudes, beliefs, and values; 2) economics and subsistence; 3) stream channel morphology; 4) sediment; 5) water; 6) fire; 7) organic debris; and 8) vegetation mosaic. Recommendations are made for the attributes of environmental indicators that characterize these elements. These elements and associated indicators will define and control management activities for the protection, preservation, and restoration of national forest giant sequoia ecosystems.
Since their discovery by settlers in 1852 , giant sequoia trees (Sequoia gigantea [Lindl.] Decne.) ${ }^{1}$ have fascinated people throughout the world (Figure 1). Early exploitation by commercial interests led to many laws and administrative decisions designed to protect the groves where these magnificent wonders of nature are found (Piirto and others 1997, Tweed 1994).

In 1990, the Sequoia National Forest was party to a mediated settlement agreement which established goals for giant sequoia management: to protect, preserve, and restore the groves for the benefit of present and future generations (USDA Forest Service 1990). In 1992, President Bush issued a proclamation that indirectly validated these goals and made them national in scope. Of the approximately 75 naturally occurring giant sequoia groves (Figure 2), 43 are found on national forests; most of the remainder are found in national parks (Rundel 1972a, Willard 1995, Rogers 1998). Portions of nine groves are in private ownership. All of the naturally occurring giant sequoia groves are found on the west slope of the Sierra Nevada mountains in California.

KEY WORDS: Ecosystem management; Environmental indicators; Natural range of variability; Giant Sequoia

\footnotetext{
${ }^{1}$ The common name, giant sequoia, and the scientific name, Sequoia gigantea (Lindl.) Decne., rather than Sequoiadendron giganteum (Lindl.) Buchholz, will be used in this paper. Justification for this is documented in Davidson (1972) and Piirto (1977).
}

\section{Management Goals}

Although the mediated settlement agreement (USDA Forest Service 1990) does not elaborate on the meaning of protect, preserve, and restore, the presidential proclamation (Bush 1992) does provide a context from which meanings useful for management purposes can be derived. In the proclamation President Bush declared: "Naturally occurring old-growth giant sequoia groves ... are unique national treasures that are being managed for biodiversity, perpetuation of the species, public inspiration, and spiritual, aesthetic, recreational, ecological, and scientific values." Among other things, he proclaimed: "The designated giant sequoia groves shall be protected as natural areas with minimum development."

\section{Scope and Context of this Paper}

The goals of protect, preserve, and restore are not independent of each other. Restoring giant sequoia ecosystems to conditions that resulted from centuries of adaptation to their environment appears to be the best way to protect them in the present, and to assure their preservation (or more appropriately, perpetuation) in the future (Fullmer and others 1996). This paper provides a scientific foundation upon which management decisions affecting these goals can be based. The foundation is developed in five steps:

1. Define the ecosystem management process as it applies to national forest giant sequoia groves 

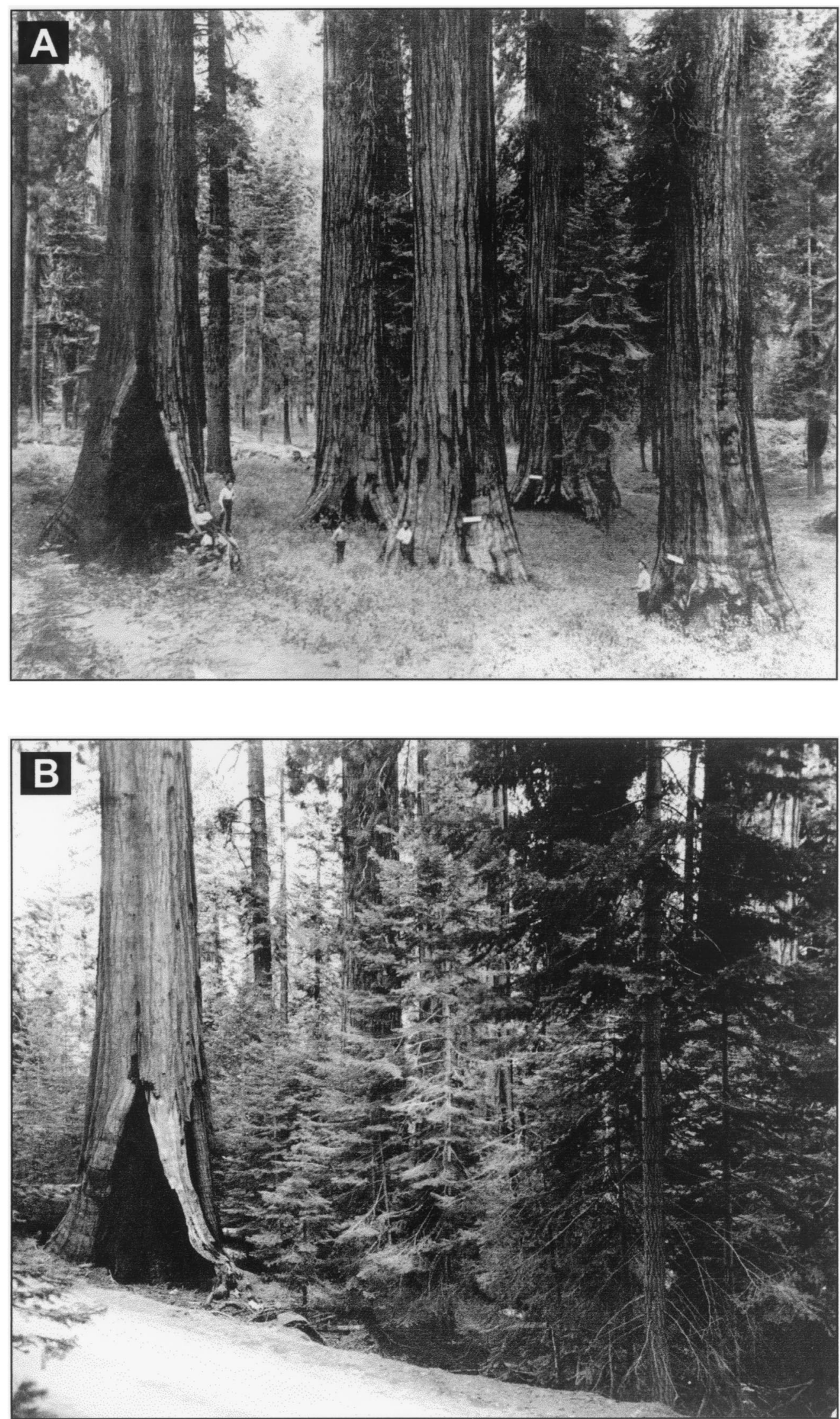

Figure 1. A The Confederate Group of giant sequoias in Mariposa Grove, Yosemite National Park. Note the signs that give each large tree an individual name. (Photo taken circa 1890.) B By 1970, in the absence of frequent surface fires, a dense thicket of white firs grew at the base of the sequoias. Such thickets provide fuels that could conduct fire high into the sequoias. (Photographs courtesy of Bruce M. Kilgore, National Park Service.) 
(most of which are currently within the Giant Sequoia National Monument administered by the USDA Forest Service). Ecosystem management combines the social, physical, and biological dimensions of the environment in a holistic way that is particularly appropriate to the goals described above.

2. Identify elements that are key to the function of giant sequoia ecosystems. This is the second step of the ecosystem management process. It identifies processes (i.e., fire and water), components (e.g., plant species), and structures (arrangement of components) that are important in characterizing giant sequoia groves.

3. Identify indicators of the key elements.

4. Describe how measures of those indicators can vary within naturally functioning giant sequoia ecosystems.

5. Provide practical guidance on how to apply the principles developed above. This context, is necessary for application of the principles developed in this paper.

\section{Ecosystem Management in the USDA Forest Service}

\section{Forest Versus Ecosystem Management}

Forest management helps people achieve their goals for forests. It seeks to produce results that meet landowner expectations, whether the owners are public or private. Leuschner (1984) states: "Forest management in the broadest sense, integrates all of the biological, social, economic, and other factors that affect management decisions about the forest." As defined by Manley and others (1995) ecosystem management is "the skillful, integrated use of ecological knowledge at various scales to produce desired resource values, products, services and conditions in ways that also sustain the diversity and productivity of ecosystems. This approach blends the physical, biological, and cultural/social needs" (Figure 3).

There appears to be no difference between the two approaches to the management of wildland natural resources, at least at the philosophical level. So, if the concept of ecosystem management brings anything new it is simply a reminder that elements of an ecosystem are interconnected, and viewing them otherwise leads to faulty assumptions about the consequences of management actions. Former Chief of the Forest Service, Dr. Jack Ward Thomas, expressed this thought when he said: "It is time to consider land use in a broader context than a series of single-use allocations to address specific problems or pacify the most vocal constituencies" (Thomas 1993).

\section{Concepts of Ecosystem Management}

Rhetoric abounds, but literature describing the actual practice of ecosystem management is scant. An exception is Manley and others (1995), a systematic process by field-oriented practitioners to put the concepts of ecosystem management to work on the ground. It deals with five basic conceptual questions: 1) How did the ecosystem develop? 2) What is sustainable? 3) What do we want (within the limits of sustainability)? 4) What do we have? 5) How do we move conditions from what we have to what we want?

These questions change the focus from output driven project planning which asks: "What do we need to mitigate because of our actions," to outcome driven planning which asks: "What do we want to create with our actions?"

The process developed by Manley and others (1995) used in this paper involves 14 steps to be applied at the landscape level:

Step 1 -select a landscape to analyze

Step 2-select key ecosystem elements and their environmental indicators

Step 3-derive recommended management variability for the indicators

Step 4-define desired condition

Step 5-determine existing condition

Step 6-compare desired condition to existing condition

Step 7-identify opportunities to approach desired condition

Step 8-list potential projects (possible management practices)

Step 9-project selection, prioritization, and scheduling

Step 10-NEPA analysis and disclosure

Step 11-responsible Official decision

Step 12-project implementation

Step 13-monitoring and feedback

Step 14-possible forest plan adjustment (adaptive management).

These steps provide a systematic and administratively feasible approach to ecosystem management.

\section{Connecting Science to Ecosystem Management}

Sustainable ecosystems require that the integrity of their components, structures, and processes (the three general types of elements) be maintained through time and space. This requires a reasonable understanding of how these ecosystems developed into their present state. Landscape conditions within all ecosystems are 


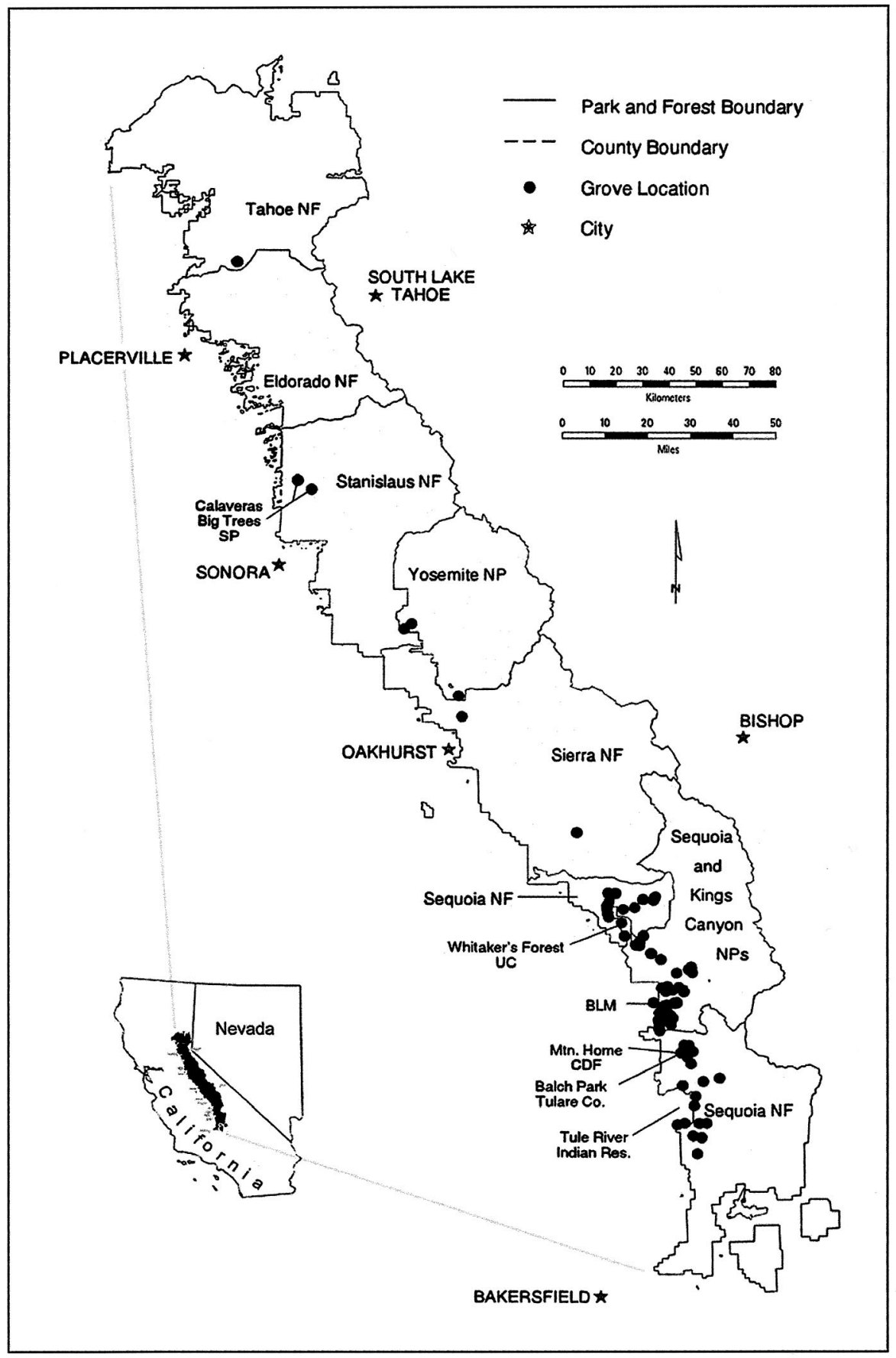

Figure 2. Locations of giant sequoia groves in the Sierra Nevada (University of California 1996).

dynamic, thus measures of their elements change over time and space, but within certain limits. An understanding of this "range of variability" is critical to ensuring the sustainability of these ecosystems. Science plays a key role in providing that understanding (Bonnicksen 1985, 1988, Stephenson 1996, Piirto and others 1997).

\section{Selecting Key Ecosystem Elements}

Ecosystem management in Region 5 of the USDA Forest Service (Figures 3 and 4 ) is guided by the concepts and principles established in "Sustaining Ecosystems-A Conceptual Framework" (Manley and others 1995). This work includes a lengthy list of ecosystem 
elements that could be helpful in defining and controlling the management actions in national forest giant sequoia groves. If all were used in practice the administrative task would become hopelessly complex. It is therefore necessary to concentrate on just the "key" ecosystem elements (Holling 1992). These are the ones that broadly represent the ecosystem, are influenced by management decisions, and are reasonably well understood (Piirto and Rogers 1999b). The selected key elements for giant sequoia ecosystems are shown in Table 1.

\section{Selecting Environmental Indicators}

Once key ecosystem elements are identified, the next step is to determine what environmental indicators will be used to assess them. From a practical administrative point of view the selected indicators should be affected by management actions, change over relatively short periods of time, be feasible to measure either directly or indirectly, and be useful in describing desired conditions (Piirto and Rogers 1999b). The selected environmental indicators for giant sequoia ecosystems that meet these criteria are shown in Table 1 (Piirto and Rogers 1999b).

\section{Natural Range of Variability}

Environmental indicators are to an ecosystem manager what an engine temperature gauge is to an automobile driver. Environmental indicators are a measure of ecosystem performance, and at the extremes of their range they often warn of danger. Just as the automobile engine temperature can range from below freezing on a cold day to the boiling point of the engine coolant on a hot one, environmental indicators also range between extremes. This range is referred to as reference variability, natural range of variability, or historic range of variability.

Manley and others (1995) elaborate as follows: "Reference Variabilities represent the full distribution of values for environmental indicators including infrequent and extreme events (e.g., severe floods, high intensity wildfires, etc.). The role of these more extreme disturbances in maintaining ecosystem processes is not well understood, but their importance for biological elements is a well-accepted notion." A desirable and more closely defined operating range is usually found between the extremes. This range is referred to as the recommended management variability (RMV). Again Manley and others (1995) elaborate: "The entire Reference Variability distribution is important and should be realized, for biological elements, over long-term,

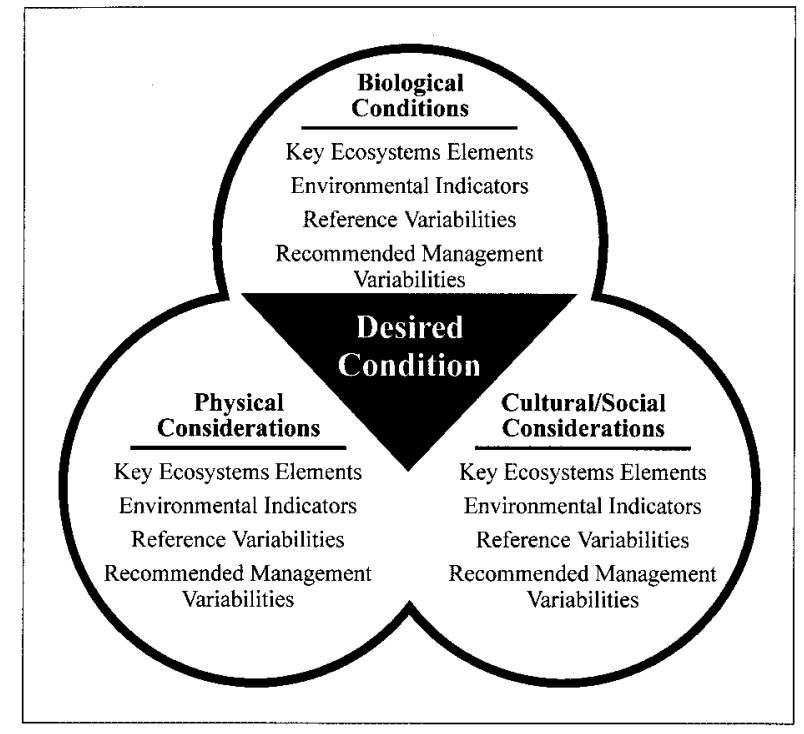

Figure 3. The USDA Forest Service Pacific Southwest region approach to ecosystem management. Biological, cultural/social, and physical considerations are integrated to arrive at a desired condition (Manley et al. 1995).

evolutionary temporal scales. However, planned management activities should not normally seek to replicate extreme values of the distribution if they will occur naturally." Under most conditions, properly designed and executed management actions should be able to maintain environmental indicators within the RMV, and by so doing minimize the risk of extreme events that would jeopardize ecosystem sustainability and resiliency (Figure 4).

The recommended management variability for any ecosystem must take into account the influence of climate on forest community development (Patterson and Prentice 1985). Over long periods of time climates do change dramatically. However, even with similar climate regimes there is substantial variation in the composition within and between the giant sequoia groves. Stephenson (1996) states in the context of the biological dimension: “. . . . It therefore seems reasonable to conclude that a variety of different grove structures, not a single predictable grove structure, probably occurred during periods that shared similar climates." Such variation can also be expected in the cultural/social and physical dimensions as well.

Indicators for all of the key giant sequoia ecosystem elements are discussed in detail in Piirto and Rogers (1999b). Because fire, organic debris, and vegetation mosaic are of paramount importance to both users and managers, indicators for these elements will be discussed here. 


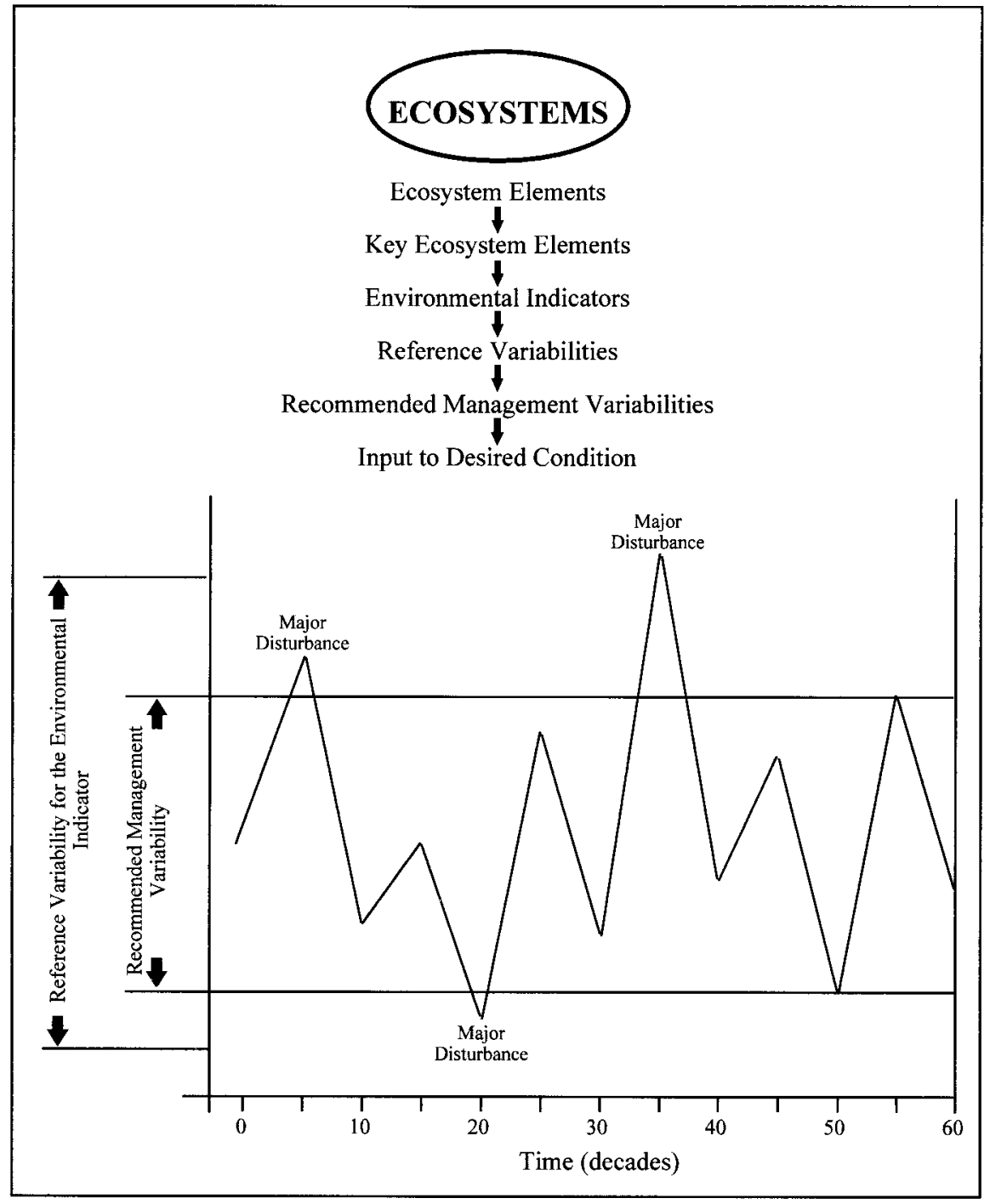

Figure 4. Relationships between ecosystem elements, indicators and recommended management variability (Manley et al. 1995).

\section{Fire Severity Indicator}

High intensity crown fires were evidently rare in the presettlement giant sequoia-mixed conifer forest (Kilgore and Taylor 1979, Muir 1961). The risk of high severity fires occurring in giant sequoia groves has increased over the last century due to a reduction in the areal extent of fire in the Sierra Nevadas. Giant sequoia mixed conifer forests now have: 1) more smaller trees with higher proportions of white fir (Abies concolor) and incense-cedar (Libocedrus decurrens) than were present historically; and 2) increased levels of fuel both on the forest floor and as fuel ladders (McKelvey and others 1996, Skinner and Chang 1996, Stephenson 1994). Stephenson (1994) states: "By far the largest deviation from equilibrium conditions (stationary age distribution) in giant sequoia populations over the last two to three millennia is due to the effects of fire suppression during the last century."

Within this context, Shulman and Gelobter (1996) developed a preliminary wildfire severity and behavior model to evaluate potential loss of spotted owl (Strix occidentalis) habitat during nintieth percentile burning conditions on the Sequoia National Forest. They used stand structure, surface fuels, slope, and weather to estimate the potential for habitat loss. They defined fire risk categories of low, moderate, high, very high, and extreme relying on BEHAVE (Fire Behavior Model) and FOFEM (First Order Fire Effects Model).

According to Mr. Jack Eaton (1996), retired USDA Forest Service Fuels Specialist, a giant sequoia grove with only $25 \%$ of its area in the high to extreme fire risk categories is likely to avoid crown fires even under ninti- 
Table 1. Recommended environmental indicators for national forest giant sequoia groves

\begin{tabular}{|c|c|}
\hline Ecosystem Elements & Recommended Environmental Indicators \\
\hline Attitudes, Beliefs, and Values & $\begin{array}{l}\text { - expression of realized expectations } \\
\text { - recognition and incorporation of diverse values and beliefs }\end{array}$ \\
\hline Economics and Subsistence & $\begin{array}{l}\text { - resource uses } \\
\text { - financial feasibility }\end{array}$ \\
\hline Stream Channel Morphology & - sinuosity, confinement, and gradient (Rosgen channel types) \\
\hline Sediment & $\begin{array}{l}\text { - vegetative bank protection (upper banks) } \\
\text { - cutting (lower banks) } \\
\text { - deposition (lower banks) } \\
\text { - scouring and deposition (channel bottom) } \\
\text { - percent stable material (channel bottom) }\end{array}$ \\
\hline Water & $\begin{array}{l}\text { - drainage density } \\
\text { - surface distribution } \\
\text { - concentration }\end{array}$ \\
\hline Fire & $\begin{array}{l}\text { - severity } \\
\text { - return rate (i.e., fire return interval) }\end{array}$ \\
\hline Organic Debris & $\begin{array}{l}\text { - weight of down material } \\
\text { - distribution of down material } \\
\text { - snag density }\end{array}$ \\
\hline Vegetation Mosaic & $\begin{array}{l}\text { - gap and patch size } \\
\text { - gap and patch frequency } \\
\text { - plant community } \\
\text { - plant species } \\
\text { - plant density }\end{array}$ \\
\hline
\end{tabular}

eth percentile burning conditions. A grove with $75 \%$ of its area in those categories is seriously threatened.

Recommendation. The potential for crown fires in giant sequoia groves should be kept at low levels. However, because of considerations for the vegetative mosaic element, there should be some allowance for patches of dense, multi-layered forest cover even though it contributes to crown fire potential. The recommended management variability for the fire severity indicator should allow between $10 \%$ and $25 \%$ of the grove area to be in the high to extreme range of potential fire severity, the remainder should be moderate to low.

\section{Fire Return Rate (Interval) Indicator}

It is generally agreed that low to moderate intensity fires in the mixed conifer forest were much more frequent prior to the late 1800's than they are today. Skinner and Chang (1996) summarized data from several authors that describe a reference variability for fire return interval of 1-35 years for the giant sequoiamixed conifer forest. Swetnam and others (1992) and Swetnam (1993) reported a fire return interval for the presettlement giant sequoia-mixed conifer forest of three to eight years with a maximum interval generally less than 15 years (Figure 5). Fire-free periods of 20-30 years occasionally appeared in the record.
Recommendation. Although the studies cited here were conducted on widely different scales (from 1 to 100 hectares), and include a variety of aspects and other factors that influence fire return interval, there appears to be consensus that the fine scale (on the order of $1 \mathrm{ha}$ ) presettlement return interval was on the order of 10 years. If prescribed fire is used extensively, then intervals very much shorter than 10 years are likely to be logistically infeasible for management to attain. On the other hand, intervals longer than about 20 years would probably allow fuels to build to excessive levels (in excess of recommended management variability) in many cases. The recommended management variability for returning low to moderate intensity fire to national forest giant sequoia ecosystems should be in the range of 5-20 years.

\section{Weight of Organic Debris-Down Material Indicator}

Stephenson (1996) and Keifer (1995) report that existing fuel loads can vary from 19 to 134 tons per acre in groves not recently disturbed. From a fire protection point of view, the less organic debris (fuel) the better. However, this same debris provides habitat for animals and plants that are important to the ecosystem in other ways, and there are administrative constraints on how much can be removed (USDA Forest Service 1993). Rog- 


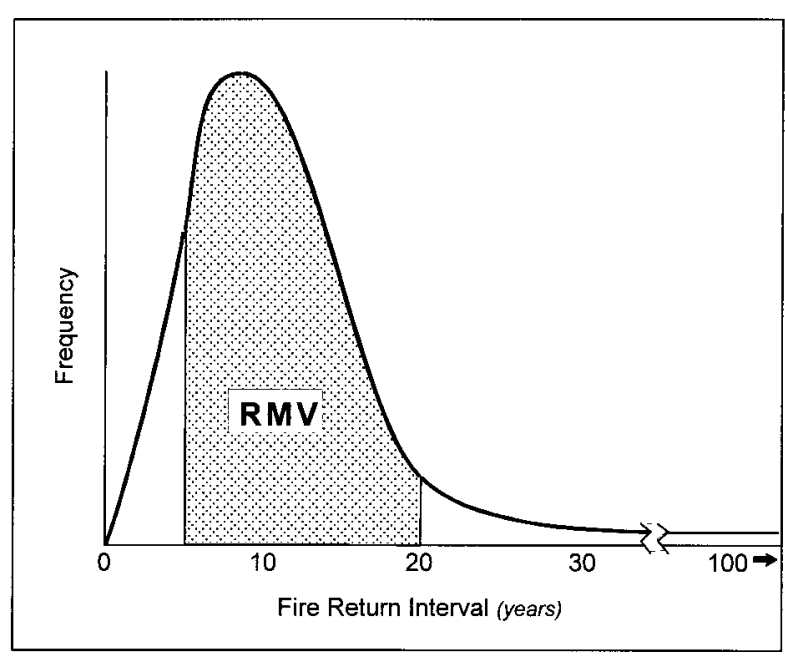

Figure 5. The return rate indicator for the fire ecosystem element. Reference variability ranges from 1 to 35 years for the giant sequoia-mixed conifer forest (Skinner and Chang 1996). The recommended management variability (RMV) for returning low to moderate intensity fire to national forest giant sequoia groves should be in the range of 5 to 20 years.

ers (1997) developed a "desired condition" for fuel within groves with this compromise in mind. However, he dealt only with fire protection, and was therefore concerned with the maximum fuel loading that would allow direct suppression under most burning conditions.

Recommendation. Until better information is available, the recommended management variability for weight of down material should be based on Rogers (1997) but modified to include minimum levels of organic debris for soil protection and other ecosystem values:

- 1-15 tons/acre forest floor (needle carpet and decomposing organic layer)

- 1-2 tons/acre for 0-1" woody material

- 1-3 tons/acre for 1-3" woody material

- 1-3 tons/acre for 3-9" woody material

- 10-20 tons/acre for $>9$ " woody material

\section{Distribution of Down Organic Material Indicator}

In 1875 John Muir observed a fire burning in the Atwell Mill Grove (Muir 1961). He noted “. . . fires seldom or never sweep over the trees. . Here they creep from tree to tree with tranquil deliberation. . Only at considerable intervals were fierce bonfires ignited where heavy branches broken off by snow had accumulated." This observation suggests that the fuelbed matrix was relatively uniform and light-likely on the order of 10-20 tons/acre. However, there were hot spots where fuel loading could have easily exceeded 100 tons/acre.
These were the places where gaps in the forest canopy could be created, even when fires were burning under moderate weather and fuel moisture conditions.

Recommendation. Until better information is available the distribution of down material should be according to weight by size class as recommended in the previous section for at least $90 \%$ of the grove area. Heavier concentrations should be confined to aggregations of one acre or less. In the event of uncontrolled wildfire this would allow for the possibility of creating canopy gaps compatible with indicators for the vegetation mosaic ecosystem element discussed later in this paper.

\section{Snag Density Indicator}

Little is known about how snags (dead trees) were distributed in the natural forest. However, it is likely that they appeared in a patchwork pattern as did other components of the vegetation mosaic. It is also likely that compared to the number of large snags that were produced by very old trees dying from insects and disease, there were many small ones caused by frequent fires and other agents. The small snags, however, were probably ephemeral in nature while the large ones may have endured for decades. There are no scientific studies that deal quantitatively with the snag density reference variability within giant sequoia groves.

Recommendation. Verner (1998) and McKelvey (1998) speculate that the natural rates of production and distribution of snags were so variable that it would be futile to manage for a predetermined snag density, even if the reference variabilities were known. As a practical matter they suggest simply managing for the natural forest and allowing snags to occur at their own rate and in their own pattern.

\section{Vegetation Mosaic Ecosystem Element}

The vegetative pattern in giant sequoia groves is made up of a variety of gaps and patches. Many authors recognize this mosaic pattern as being an important attribute of the groves (Bonnicksen and Stone 1981, 1982 a, b, Stephenson and others 1991, Stohlgren $1993 \mathrm{a}, \mathrm{b})$. Huntington (1914) noted that giant sequoia trees generally grow in groups of 6 trees of the same age forming a circle. Stephenson et al. (1991) report that the Parker, Senate, House, and Founders groups in Giant Forest range in size from 0.1 ha to 0.2 ha with 5 to 20 large giant sequoia trees of similar age. They further report that the largest cohort of giant sequoia regeneration caused by prescribed fire in Sequoia and Kings Canyon National Park is about 4 ha with patchiness of giant sequoia regeneration being a function of patchiness of fire disturbance. The distribution of other 

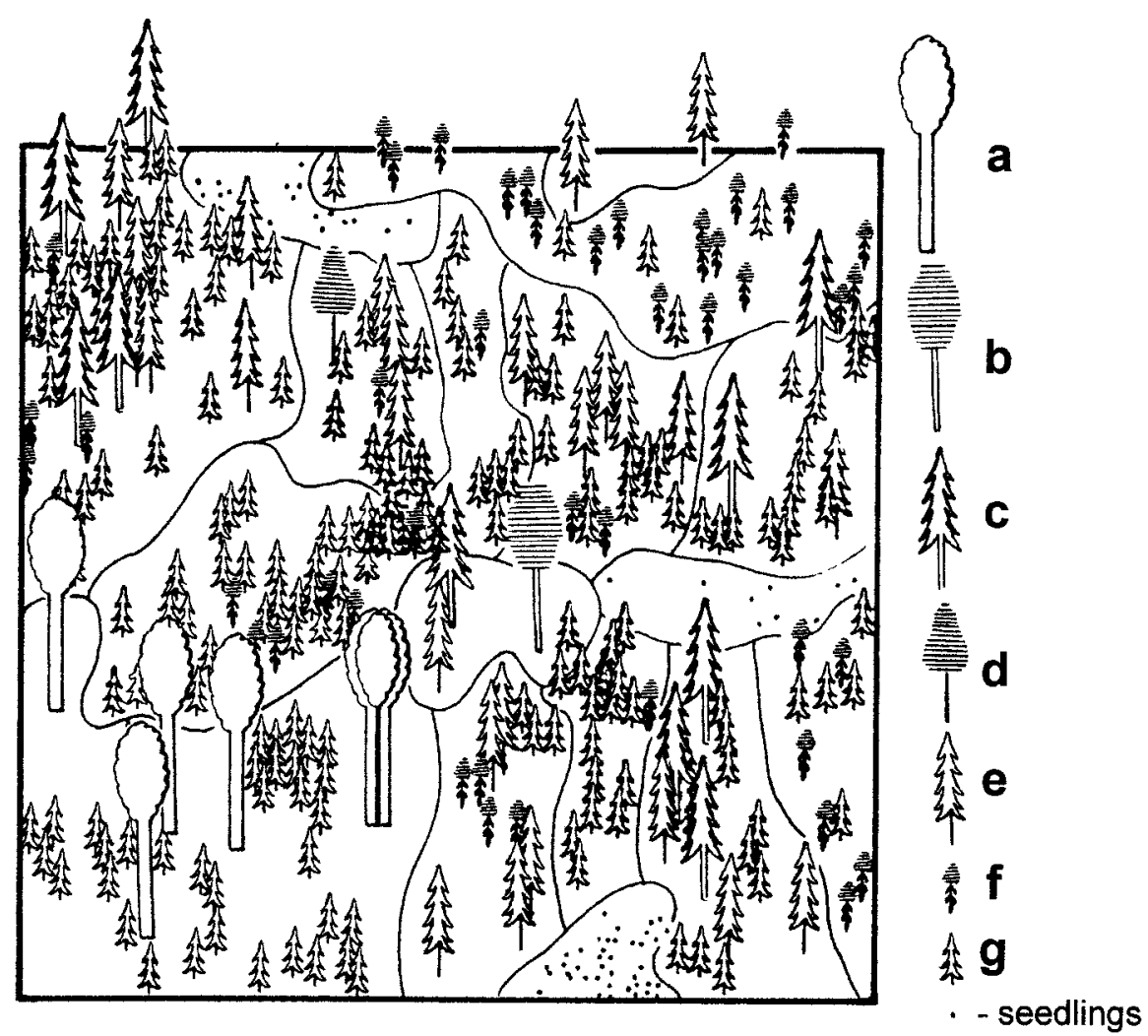

Figure 6. Sequoia grove structure and dynamics can be understood in terms of a mosaic of forest gaps and patches. This schematic diagram shows the location of trees in a $50 \mathrm{~m}$ by $50 \mathrm{~m}$ (164 ft by $164 \mathrm{ft}$ ) section of the Redwood Mountain Grove, unburned for about a century. Lines are meant to accentuate the forest mosaic by delimiting patches of relatively uniform forest structure and composition, though it is clear that patch boundaries are not always distinct and their designation can be somewhat arbitrary. The tree symbols

vegetation follows a similar pattern. Bonnicksen and Stone (1981, $1982 \mathrm{a}, \mathrm{b})$ report that existing aggregations in Redwood Mountain Grove range in size from 135 to $1600 \mathrm{~m}^{2}$ (0.01 to $0.16 \mathrm{ha}$ ) with most overstory aggregations generally less than $800 \mathrm{~m}^{2}$ (0.08 ha).

The forest mosaic as depicted by Bonnicksen (1982 a, b, 1993 a, b) is illustrated in Figure 6. The boundaries of gaps and patches in giant sequoia groves are characterized as being diffuse, often without sharp edges with many gaps having living trees that survived the effects of fire disturbance (Demetry and Duriscoe 1996). This is important in that restoration work must focus both on gap and patch development as well as vegetation condition within the entire forest mosaic. It is critical to realize that in the natural or "ancient" forest only a few patches (on the scale of a fraction to a few hectares) may be dominated by large, old trees. However, large represent: a, giant sequoias greater than $35 \mathrm{~m}$ (115 ft) tall; b, sugar pines greater than $35 \mathrm{~m}$ tall; c, white firs greater than $35 \mathrm{~m}$ tall; d, sugar pines 10 to $35 \mathrm{~m}$ (33 to $115 \mathrm{ft}$ ) tall; e, white firs 10 to $35 \mathrm{~m}$ tall; f, sugar pines 3 to $10 \mathrm{~m}$ (10 to $33 \mathrm{ft}$ ) tall; g, white firs 3 to $10 \mathrm{~m}$ tall; $\cdot$, seedlings. For clarity, the tree symbols are reduced in size relative to the plot, lending a somewhat open appearance to the stand. (Adapted from Bonnicksen and Stone [1982a, b, 1993a, b], with permission of the Ecological Society of America.)

old trees will be scattered throughout the forest mosaic (on a scale of hundreds of ha) giving the entire landscape an "old growth," "ancient forest," or "late seral stage" character.

\section{Gap and Patch Size Indicator}

Demetry and Duriscoe (1996) studied fire-caused gaps as part of the research needed for ecological restoration of Giant Forest Village in Sequoia National Park. They analyzed the vegetation response in 18 gaps of three different sizes that were created by prescribed fire within the last 15 years. The gaps ranged in size from 0.067 ha to 1.17 ha.

Stephenson and others (1991) and Stephenson (1994) reported even-aged patches ranging in size from 0.03 to $0.4 \mathrm{ha}$. The minimum size of gap leading to successful recruitment of giant sequoia appeared to be 
around 0.1 ha. Gaps larger than 10 ha created by avalanches or single or repeated fires are reported as being a rare occurrence within most presettlement giant sequoia groves (Fry 1933, 1948, Stephenson and others 1991, Caprio and others 1994, Stephenson 1994, 1996).

Stephenson (personal communication: 1998) speculates that perhaps two thirds of all gaps in presettlement times were less than 0.20 ha in size. Based on work in the Redwood Mountain Grove, Bonnicksen (1993 a, b) reiterates that even-aged groups of trees in ancient giant sequoia forests were generally less than 0.08 ha in size. However, the gaps from which these groups developed were probably larger than that (Stephenson 1987). Available information suggests that most gaps created by natural causes within giant sequoia groves probably ranged from 0.04 to 0.8 ha $(0.1$ to 2 acres $)$ in size as shown in Figure 7. This figure is constructed from an estimate of presettlement distribution of gaps of different sizes based on work by Bonnicksen and Stone $(1978,1982 \mathrm{a})$ and personal communication with Stephenson (1998).

Recommendation. Most gaps and patches of vegetation that arise from them, should be at least .08 ha. The recommended management variability should range from 0.04 to 0.80 ha (Figure 7 ).

\section{Gap and Patch Frequency Indicator}

No empirical data exists to verify the exact amount of area within a giant sequoia grove that was disturbed during any given period in presettlement times. However, some clues to this question can be gained from Bonnicksen and Stone's (1982 a, b) work. They estimated that in 1890 the Redwood Mountain Grove contained $7 \%$ of the area in aggregations dominated by bare soil (gaps), $6 \%$ grass and forbs, $10 \%$ seedling trees (trees less than $3 \mathrm{~m}$ in height), 19\% brushland, and $17 \%$ saplings (trees $3-10 \mathrm{~m}$ in height). These conditions suggest that about $13 \%$ of the area was subject to recent disturbance (the bare soil, grass, and forb aggregations). Stephenson (personal communication: 1998) suggests gaps created within a given decade probably occupied significantly less than $10 \%$ of the landscape. This is consistent with the $7 \%$ bare soil area estimated by Bonnicksen and Stone (1982 a, b). Bonnicksen and Stone (1982 a, b) also estimate that $15 \%$ of the area was dominated by pole-size trees (trees $10-35 \mathrm{~m}$ in height), $9 \%$ by mature trees $(>35 \mathrm{~m}$ in height but $<1.2 \mathrm{~m}$ in diameter breast height), $10 \%$ by large mature trees $(>$ $35 \mathrm{~m}$ in height and $>1.2 \mathrm{~m}$ in diameter breast height), and $7 \%$ was occupied by rock or unclassified vegetation (Figure 8).

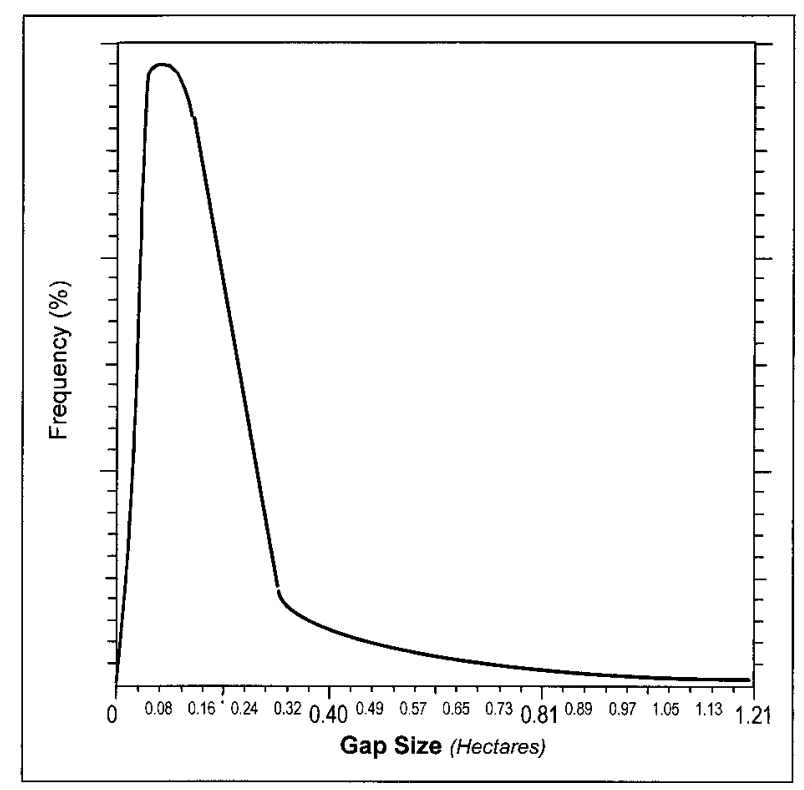

Figure 7. The gap size and frequency indicators for the Vegetation Mosaic ecosystem element. An approximation based on anecdotal data provided by Stephenson (1998) and empirical data in Bonnicksen and Stone (1981, 1982a, b), Stephenson (1991, 1994, 1996), Caprio and others (1994), Demetry and Duriscoe (1996). Even though two-thirds of all presettlement gaps were probably less than 0.20 ha, they accounted for only one-third of all gap area.

\section{Recommendation.}

- Recently created gaps in the forest canopy $(<10$ years old), other than sites with unproductive soils, should occupy $1-10 \%$ of grove area.

- Early seral stage patches (vegetation 10-20 years old) should dominate on $30-40 \%$ of grove area.

- Mid-seral stage patches (20-150 years old) should dominate on $40-50 \%$ of the grove area.

- Patches of late seral stage vegetation ( $>150$ years old) should occupy $10-20 \%$ of grove area.

Consideration should be given to the fact that gap and patch boundaries tend to be diffuse and that remnants of seral stages other than the dominant one can occupy portions of a gap or patch. There can be "young" understory vegetation in late seral patches, and "old" overstory in early seral patches, and various other combinations within a given gap or patch.

\section{Tree Species Composition (Plant Community Indicator)}

According to Rundel (1971) giant sequoia groves are differentiated from adjacent mesic habitats in the mixed conifer forest only by the presence of giant 
Figure 8. The plant community indicator of landscape area for the Vegetation Mosaic ecosystem element based on empirical data provided by Bonnicksen and Stone (1982a, b) for Redwood Mountain Grove. Illustrated in this figure is the estimated amount of landscape area occupied by different vegetation types. A similar shift in vegetation types has been anecdotally observed for other national forest giant sequoia groves.

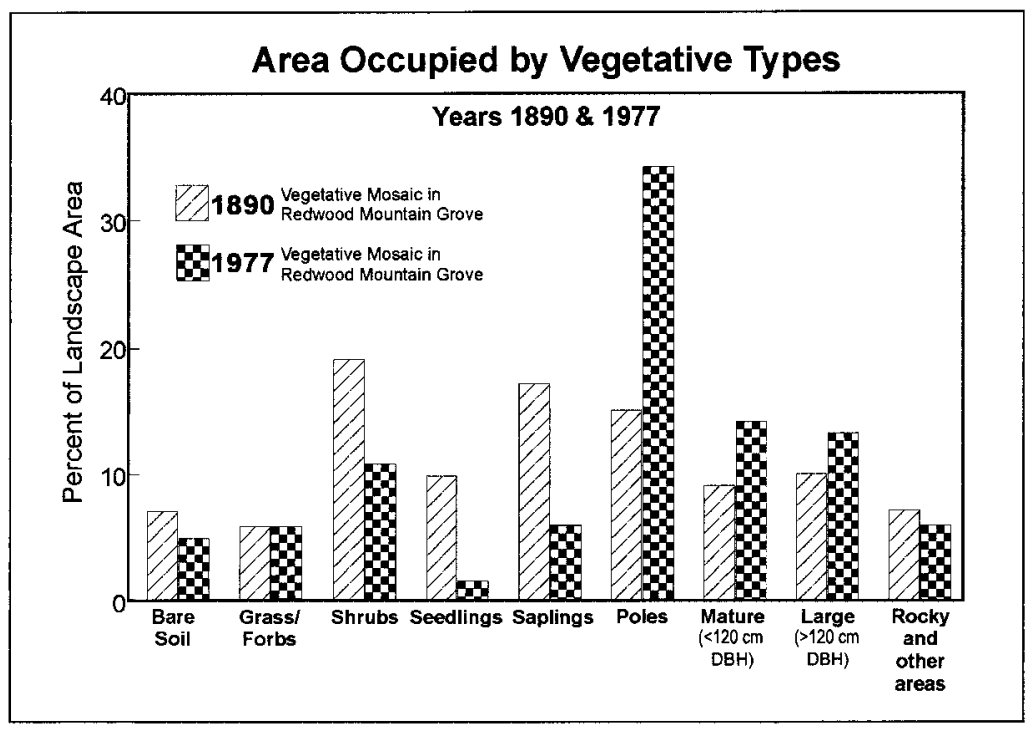

sequoia. Other plant species in giant sequoia groves probably vary in abundance in response to the same conditions that promote the giant sequoia. Pacific dogwood (Cornus nuttallii), for example, is a moistureloving plant. It frequently seems more prevalent in giant sequoia groves than the surrounding forest. It appears that there have been no changes in the dominant trees species present in giant sequoia groves when compared to presettlement times, but there have been dramatic changes in density, age structure, and the overall vegetation pattern (Stephenson 1996).

There is general agreement that the absence of fire in most of the giant sequoia groves has resulted in an increase of white fir, reduced regeneration of giant sequoia and pines, and reduced density of shrubs and hardwoods (Hartesveldt and Harvey 1967, Kilgore and Taylor 1979, Harvey and others 1980, Bonnicksen and Stone 1982 a, b). Bonnicksen and Stone (1982 a, b) found that the proportion of the area occupied by conifer aggregations has increased from $49 \%$ in 1890 to $63 \%$ in 1977 . The number of aggregations dominated by white fir increased from $27 \%$ in 1890 to $37 \%$ in 1977 . However, Stephenson (1987) contends that Bonnicksen and Stone (1982 a, b) underestimated the amount of white fir in 1890, particularly in the overstory.

Considerable information is available on tree stocking density for the mixed conifer forest in general (Dunning and Reineke 1933), but little is specific to giant sequoia groves. Stephenson (1994) discusses age distribution and Stohlgren (1991, 1992, 1993 a, b) discusses basal area and tree distribution of giant sequoias within selected groves. Rundel (1971) provides valuable information on basal area and frequency of occurrence by major tree species within groves. All of these studies are contemporary; the data include changes from the past 100-150 years of "settlement." Nevertheless, they do provide a basis for speculating on how the presettlement groves may have been structured.

Stohlgren's cumulative frequency giant sequoia tree data for 31 National Park groves (1991), for example (Figure 9), shows that over $90 \%$ of the existing giant sequoia basal area is in trees $>152 \mathrm{~cm}$ in diameter. Trees of this size were almost certainly well established at least 100 year ago, and probably persisted with about the same mortality that would be expected even with the periodic low intensity fires of presettlement times. Thus, except for perhaps $10 \%$ of the total basal area, contemporary basal area distribution for giant sequoias appears to be a reasonable representation of the presettlement distribution. For the size classes representing structure development since settlement, basal area in larger trees (say 76 and $152 \mathrm{~cm}$ in diameter) probably is greater than presettlement values because these trees did not experience significant thinning by fire. On the other hand, basal area in smaller trees is probably under-represented because seedlings were not being established in the undisturbed, closed canopy forest (Stephenson 1994).

Rundel (1971) provides data on basal area distribution (relative dominance) by species in four groves. However, these data may not give a close approximation to presettlement. Willard (1995) provides anecdotal data that helps with the interpretation of mixed species within giant sequoia groves. He analyzed 23 sets of cruise data taken in five groves between 1908 and 1936. (All but five of the sets were taken in 1908.) Giant 


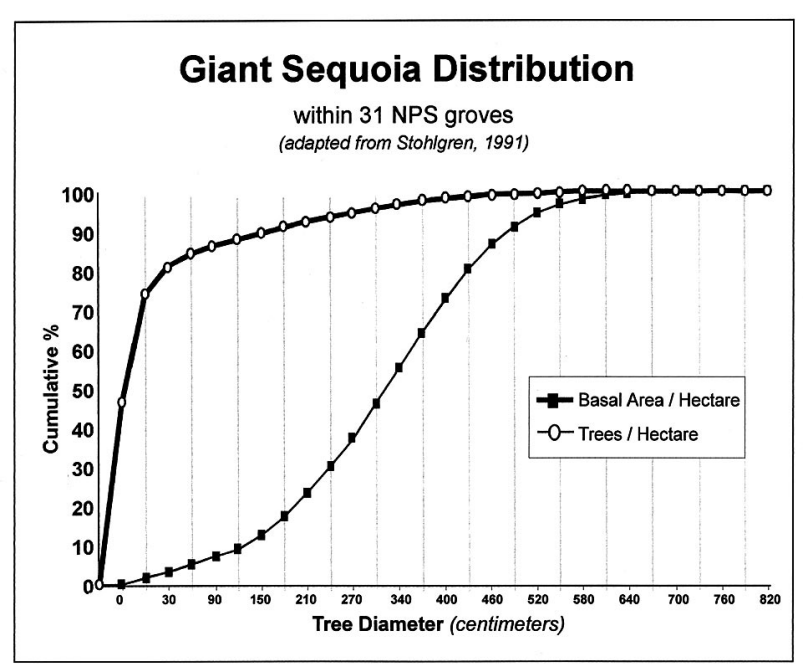

Figure 9. Distribution of giant sequoia trees as expressed by numbers of trees and basal area per hectare.

sequoia ranged $57-87 \%$ of the total merchantable board foot volume, the average being $73 \%$. Although cruise procedures are unknown it is almost certain that the basal area proportion of giant sequoia was less than the cruise proportion. This is because cruise volume is a function of basal area times height, and the giant sequoia trees that account for most of the basal area are taller than most other conifers in these stands. Thus for the same volume, giant sequoias require less basal area than the other conifers. However, some of this difference, which could be on the order of $40-50 \%$, could be offset by breakage estimates used by the cruisers. They surely estimated greater breakage, and hence a proportionally lower net volume, than for the other conifers. If Willard's giant sequoia volume proportion is reduced by, say, $10 \%$ to compensate for giant sequoia height and breakage differences, Willard's data corroborates Rundel's very well. Rundel's (1971) data on four groves averages $65 \%$ dominance (basal area) for giant sequoia, Willard's (based mostly on 1908 data) would estimate $63 \%$ on average. Surprisingly, it appears that contemporary relative dominance by species is similar to presettlement times. This probably is not true for the mixed conifer forest in general where there has been significantly more disturbance. However, even here McKelvey and Johnston (1992) estimate only a 10-20\% shift toward white fir dominance.

The same cannot be said about relative density (numbers of trees per ha). In contemporary groves Rundel (1971) shows that giant sequoias account for $5-11 \%$ of trees present and white fir 54-85\%. Many suggest there were many more young giant sequoias and fewer white fir in presettlement times (Hartesveldt and Harvey 1967, Rundel 1971, Kilgore and Taylor 1979, Harvey and others 1980, Bonnicksen and Stone 1982 a, b). Muir (1961) corroborates this suggestion with anecdotal observations such as: "On a bed of sandy ground 15 yards square, which had been occupied by four sugar pines, I counted ninety-four promising seedlings, an instance of sequoia gaining ground from its neighbors. Here also I noted eighty-six young sequoias from 1 to 50 feet high on less than half an acre of ground that had been cleared and prepared for their reception by fire." Willard (1995) does not have corroborating evidence from cruise data. However, it is safe to say that young giant sequoias (seedlings to trees perhaps $76 \mathrm{~cm}$ in diameter) were relatively more abundant and other species, primarily white fir, were less abundant in presettlement times.

Recommendation (Tree and Plant Species). Intuition suggests that for ecosystem resilience and stability the array of plant species currently existing (other than exotics) should be maintained. Until better information is available, no other species should be introduced and seeds for giant sequoia planting within a grove should come from trees within that grove (Fins and Libby 1982, Fins and Libby 1994). Until more is known about their presettlement distribution, the abundance of shrubs and herbaceous plants should be allowed to vary according to their natural propagation following natural or management induced disturbance. Based on work done by Rundel (1971), Stohlgren (1991), and Willard (1995) tree species recommendations for groves are:

- Giant sequoias should account for approximately 55$75 \%$ of total basal area and $\geq 10 \%$ of the total trees.

- The mixed conifer component should contain 25$45 \%$ of the total basal area with white fir (Abies concolor) being the dominant species. Incense cedar (Calocedrus decurrens), sugar pine (Pinus lambertiana), ponderosa pine (Pinus ponderosa), and black oak (Quercus kelloggii) are also important components of most groves, but even in combination should occupy $\leq 20 \%$ of the total basal area.

- For less common associates, no recommendations are made at this time other than to recognize their legitimacy. These species include Jeffrey pine (Pinus jeffreyi), Douglas-fir (Psuedotsuga menziesii), red fir (Abies magnifica), Pacific yew (Taxus bervifolia), Pacific dogwood, California hazel (Corylus cornuta var. californica), white alder (Alnus rhombifolia), Scouler willow (Salix scouleriana), bigleaf maple (Acer macrophyllum), bitter cherry (Prunus emarginata), and canyon live oak (Quercus chrysolepis). 
Table 2. Reference variability for number of giant sequoia trees and basal area per hectare ${ }^{a}$

\begin{tabular}{|c|c|c|c|c|}
\hline $\begin{array}{l}\text { Diameter Class } \\
(\mathrm{cm})\end{array}$ & Average Trees/Ha & Range of Trees/Ha & $\begin{array}{l}\text { Average Basal Area/Ha } \\
\qquad\left(\mathrm{m}^{2}\right)\end{array}$ & Range of Basal Area/Ha \\
\hline 7 & 19.5 & $0.0-45.0$ & 0.07 & $0.0-0.17$ \\
\hline 30 & 11.4 & $0.2-31.6$ & 0.81 & $0.2-2.25$ \\
\hline 60 & 3.0 & $0.5-14.6$ & 0.83 & $0.15-4.12$ \\
\hline 90 & 1.5 & $0.2-8.4$ & 0.86 & $0.12-5.36$ \\
\hline 120 & 0.7 & $0.0-7.4$ & 0.89 & $0.0-8.50$ \\
\hline 150 & 0.7 & $0.2-4.9$ & 1.11 & $0.22-8.84$ \\
\hline 180 & 0.7 & $0.0-4.9$ & 1.58 & $0.0-12.72$ \\
\hline 210 & 0.7 & $0.0-1.5$ & 2.20 & $0.0-4.89$ \\
\hline 240 & 0.7 & $0.0-1.5$ & 2.84 & $0.0-6.32$ \\
\hline 270 & 0.5 & $0.0-1.5$ & 3.11 & $0.0-8.57$ \\
\hline 300 & 0.5 & $0.0-1.7$ & 3.41 & $0.0-12.37$ \\
\hline 340 & 0.5 & $0.0-2.5$ & 4.08 & $0.0-22.70$ \\
\hline 370 & 0.5 & $0.0-1.0$ & 4.40 & $0.0-11.73$ \\
\hline 400 & 0.2 & $0.0-1.0$ & 4.32 & $0.0-13.71$ \\
\hline 430 & 0.2 & $0.0-1.0$ & 3.98 & $0.0-13.19$ \\
\hline 460 & 0.2 & $0.0-0.7$ & 3.51 & $0.0-13.61$ \\
\hline 490 & 0.2 & $0.0-0.7$ & 3.06 & $0.0-12.00$ \\
\hline 520 & $<0.2$ & $0.0-0.2$ & 1.95 & $0.0-4.5$ \\
\hline 550 & $<0.2$ & $0.0-0.5$ & 1.78 & $0.0-5.95$ \\
\hline 580 & $<0.2$ & $0.0-0.2$ & 1.09 & $0.0-1.95$ \\
\hline 610 & $<0.2$ & $0.0-0.2$ & 0.67 & $0.0-2.67$ \\
\hline 641 & $<0.2$ & $0.0-0.2$ & 0.44 & $0.0-4.03$ \\
\hline 670 & $<0.2$ & $0.0-0.2$ & 0.17 & $0.0-2.05$ \\
\hline 700 & $<0.2$ & $0.0-0.2$ & 0.10 & $0.0-0.42$ \\
\hline 730 & $<0.2$ & $0.0-0.2$ & 0.05 & $0.0-0.20$ \\
\hline 760 & $<0.2$ & $0.0-0.2$ & 0.02 & $0.0-0.12$ \\
\hline 790 & $<0.2$ & $0.0-0.2$ & 0.02 & $0.0-0.07$ \\
\hline 820 & $<0.2$ & $0.0-0.2$ & 0.05 & $0.0-0.17$ \\
\hline 850 & $<0.2$ & $0.0-0.2$ & 0.02 & $0.0-1.11$ \\
\hline
\end{tabular}

aThe average and range of values shown are based on studies completed by Hammon and others (1964, 1970, 1975, 1976), Western Timber Service (1970), Stohlgren (1991) for 31 national park giant sequoia groves containing 30 or more giant sequoia trees.

Recommendation (Tree and Plant Densities). As discussed above, recommending management variability for tree densities (trees per hectare by size and species) is problematical, particularly for the smaller size classes. For steady state sustainability on a scale of 10 to 100 ha, though, to account for mortality, each smaller size class must have progressively more members than the preceding one. One such distribution for giant sequoia is illustrated in Table 2. It is based on Stohlgren's (1991) work for the larger sizes with estimates for the smaller sizes. For practical application in the field Table 3 condenses Stohlgren's data set (Table 2) and this same information is graphically depicted in Figures 10 and 11. It is assumed other tree species will be distributed in a similar (uneven-aged) fashion. Guldin (1991) provides one approach for defining the relationships between size (as a proxy for age), number of trees, and basal area per hectare. By combining the work of Rundel (1971) and Stohlgren (1991) one can conclude that average basal area stocking for groves should be on the order of $48 \mathrm{~m}^{2}$ per hectare for giant sequoia and $25 \mathrm{~m}^{2}$ per hectare for other species. These figures include the basal area of trees that exist in the forest as a result of fire suppression in the last century. However, the contribution of these trees to total basal area is relatively small, as shown in Figure 8, especially in the case of giant sequoia, because most of the basal area is accounted for by trees $>$ than 100 years old.

\section{Interpretation and Application}

\section{Overview}

The information provided in this paper is intended to serve as an ecological basis for site-specific grove management planning. Recommendations given here will be improved upon as scientists add to the body of giant sequoia knowledge, and as monitoring provides feedback on the short- and long-term effects of management actions. Adaptive management will create a strong link between science and management of national forest giant sequoia ecosystems. The purpose of 
Table 3. Recommended management variability (RMV) for giant sequoia trees ${ }^{a}$

\begin{tabular}{ccccc}
\hline $\begin{array}{l}\text { DBH Size Group } \\
(\mathrm{cm})\end{array}$ & Average Trees/Ha & $\begin{array}{c}\text { RMV for Trees/Ha } \\
\text { Range }^{\text {a,b,c }}\end{array}$ & $\begin{array}{c}\text { Average Basal Area/Ha } \\
\left(\mathrm{m}^{2}\right)\end{array}$ & $\begin{array}{c}\text { RMV for Basal Area/Ha Range } \\
\left(\mathrm{m}^{2}\right)\end{array}$ \\
\hline $0.25-14.99$ & 19.5 & $25-99$ & 0.007 & $0.05-0.14$ \\
$14.99-44.96$ & 11.4 & $12-20$ & 0.80 & $0.12-0.34$ \\
$44.96-74.93$ & 3.0 & $5-25$ & 0.85 & $0.22-0.91$ \\
$74.93-165.10$ & 3.0 & $2-10$ & 2.85 & $0.91-3.67$ \\
$165.10-285.0$ & 2.7 & $2-5$ & 9.72 & $3.21-9.38$ \\
$285.0-475.0$ & 2.2 & $0-5$ & 23.6 & $0.00-27.22$ \\
$>475.0$ & 0.2 & $0-5$ & $\underline{47.40}$ & $0.00-75.70$ \\
TOTAL & $\overline{42.0}$ & & 47.2 & \\
\hline
\end{tabular}

${ }^{a}$ Recommended management variability is based on a complete giant sequoia tree inventory of 31 national park groves with more than 30 giant sequoia trees present (Hammon and others 1964, 1970, 1975, 1976, Western Timber Service 1970, Stohlgren 1991). Original grove size estimates used by Stohlgren were modified to reflect current information. Stohlgren estimated 8,277 acres (3,351 ha), current estimates show 9,665 acres $(3,913 \mathrm{ha})$ in the 31 national park groves. This difference in size affects per hectare and per acre calculations and explains why numbers shown here do not correspond directly to Stohlgren's per hectare values.

${ }^{b}$ Probable range needed for sustainability—not substantiated by empirical or other data.

${ }^{\mathrm{C} N o}$ giant sequoia grove is known to have on average more than 2 trees per acre in these size classes.

this section is to provide a context for practical application.

\section{Completing the Ecosystem Management Process}

This paper has concentrated on giant sequoia ecosystems, their elements, associated environmental indicators, and reference variability. These are critical variables in the process of ecosystem management planning, but identifying and quantifying them only completes three steps out of the 14-step process discussed by Manley and others (1995). The context in which ecosystem elements and environmental indicators are applied in practice must take into account all 14 steps in the planning process with significant emphasis on Steps 1 and 14 (landscape to analyze and adaptive management).

\section{Selecting the Landscape Area}

The first step in the Manley and others (1995) ecosystem management process is to select a landscape for analysis. The focus of this paper has been on grove ecosystems, the boundaries of which are defined by the outermost giant sequoia trees within the groves. The paper does not attempt to deal with external influences. However, the ecosystem management process must take into account the larger landscape of which the groves are a part. An approach to defining the ecologically rational zone of influence for giant sequoia groves should definitely take into account two of the key elements identified in this paper: fire and water (Rundel 1972b, Anderson 1995, University of California 1996). Using this approach, and with only rudimentary knowledge of fire behavior and hydrology, leads to the conclusion that sub-watersheds that contain the groves should be the landscape of concern. More specifically, fire influence is of concern in those portions of the sub-watershed that lie below the grove, and water influence is of concern for those portions that lie directly around and above the grove.

\section{Management Caveats}

The following observations are intended to assist with the practical application of the information presented in this paper:

- Recommended management variability (RMV) includes a range of values within reference variability that implies a high degree of resilience and sustainability for the ecosystem. RMVs most often describe mid-range values under the assumption that the extremes should be rare and will occasionally exist whether or not there is a deliberate attempt to create or maintain them.

- Allowing indicators to routinely exist at extremes, or outside the range of variability, probably decreases ecosystem resilience and sustainability in most cases. In rare cases such as the realized expectation indicator for the Attitudes, Beliefs, and Values Ecosystem Element, values at the extreme can sometimes be very desirable (Piirto and Rogers 1999b).

- The need for management action (management opportunity) is indicated by a difference between existing condition and RMV.

- Part of the variation within reference variability is random (e.g., mortality is influenced by weather pattern during a particular fire event), and part is systematic (e.g., species composition is influenced 


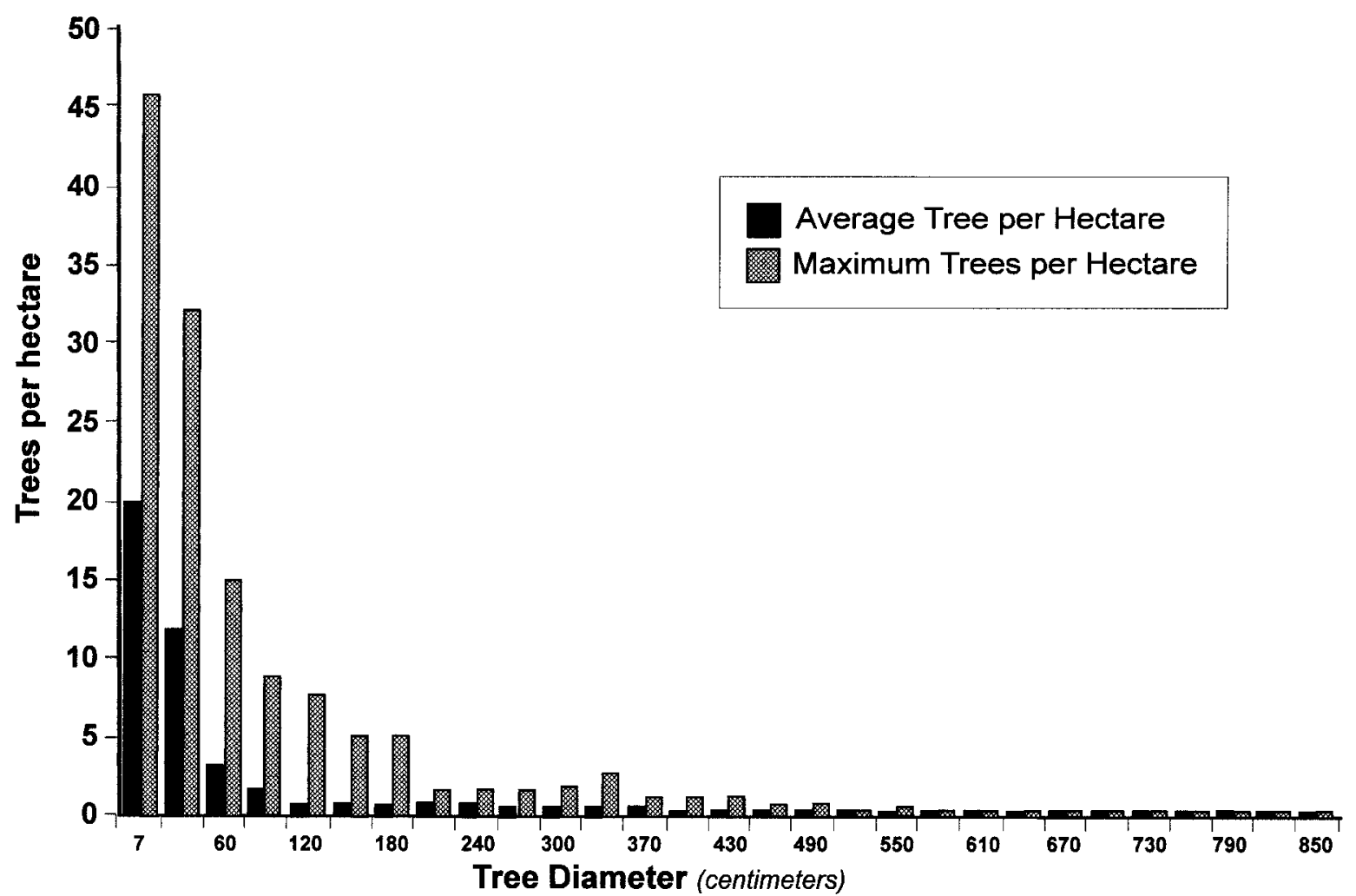

Figure 10. Distribution of giant sequoia trees within 31 NPS groves as expressed by numbers of trees per hectare (adapted from Stohlgren 1991).

by aspect and elevation). Deciding where to operate within RMV therefore requires a knowledge of the physical and biological landscape as well as the cultural/social context in which management decisions are made.

- Sustainability of range-wide grove attributes is not necessarily dependent on sustainability of individual grove attributes (e.g., it may be acceptable, or even desirable, for one grove to be deficit in an attribute if another grove is surplus). In fact, for certain attributes this is very much the way things work in nature. Not all giant sequoia groves are going to have trees as large as the General Sherman. Therefore, any proposal to correct the difference between RMV and existing conditions in a specific grove should consider whether or not it is important to take into account the existing conditions in all the other groves.

- In the social dimension be wary of the interpretation of the "limit of acceptable change". Regardless of scientific validity, diverse values and cultural inertia will allow change to happen only so fast.

- The concepts of ecosystem management presented in this paper are relatively new. Therefore, in the application of RMVs developed in this paper, common sense in relation to known science and sitespecific conditions should prevail.

\section{Concluding Comments}

The key ecological elements, environmental indicators, and the quantification of indicators presented in this paper must be subject to review and revalidation. Members of the recently formed Giant Sequoia National Monument Science Board (Clinton 2000) and Giant Sequoia Ecology Cooperative (USDA 1996) should be an integral part of this adaptive management process.

Not seeing the forest for the trees has been a common expression in forestry. We have observed through this work that our past and present efforts to classify vegetation and ecosystems often masks our view of the finer scale of diversity that exists within these types.

We have also learned through this work that the restoration and maintenance of healthy forest ecosystems cannot simply focus on process. Rather, an understanding of structure and process at both the 


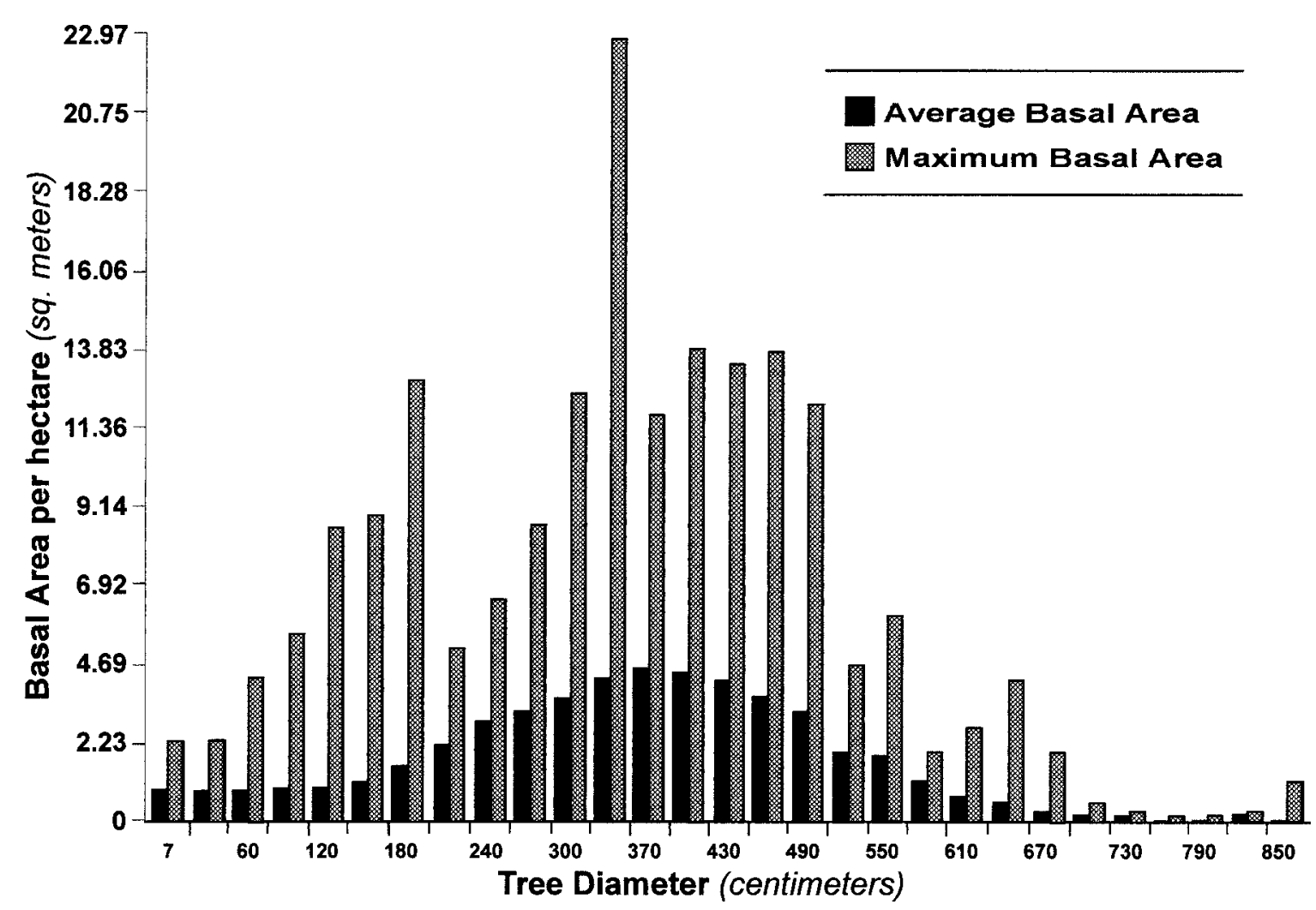

Figure 11. Distribution of giant sequoia trees within 31 NPS groves as expressed by basal area per hectare (adapted from Stohlgren 1991).

landscape (coarse) and plant aggregation (fine) scales is essential.

\section{Acknowledgments}

This paper is condensed from a more detailed analysis and annotated bibliography titled "An Ecological Foundation for Management of National Forest Giant Sequoia Ecosystems" (Piirto and Rogers, 1999b). The initial abbreviated copyrighted version of this paper was published in the proceedings for the Sixty-fourth North American Wildlife and Natural Resources Conference (Piirto and Rogers 1999a). A major updated revision of the abbreviated version is being presented here with permission of the Wildlife Management Institute.

For financial and administrative assistance, we thank the U.S. Department of Agriculture-Forest Service, Sierra Forest Industries, and Save-the-Redwoods League. Acknowledgment is given to the individuals, agencies, and organizations which comprise the Sequoia National Monument Science Board and Giant Sequoia Ecology Cooperative. These groups were formed to provide leadership in applied research on the ecology and management of giant sequoia-mixed conifer forests.

For their encouragement, ideas, and support, we thank: A. Gaffrey (Forest Supervisor), M. ChislockBethke, J. Mincks, L. Brett, J. Allen, L. Jump, T. KaplanHenry, and the personnel of the Sequoia National Forest; J. Boynton (Forest Supervisor), M. Smith, and J. Exline of the Sierra National Forest; S. Paulson, J. Fiske and D. Dell'Ario of the USDA Forest Service Region Five Office; H. Salwasser, G. Mason and the personnel of the USDA Forest Service Pacific Southwest Research.

The quality of the larger paper upon which this abbreviated version is based has been enhanced through thoughtful reviews provided by: A. Gonzalez Caban, Research Economist with USDA Forest Service; S. Carter (Botanist), R. Lewis (Ecologist), and R. Fellows (Field Office Manager) with USDI Bureau of Land Management; N. Stephenson (Research Scientist), J. Manley (Supervisory Natural Resources Specialist), and M. Tollefson (Park Superintendent) with USDI National Park Service Sequoia and Kings Canyon National Parks; T. Swetnam, Associate Professor of Dendrochronology and Watershed Management at University of 
Arizona, Tucson; D. Leisz, Retired Associate Chief, USDA Forest Service, Washington, D.C.; T. Bonnicksen, Professor of Forestry, Texas A\&M University; D. Fullmer, Ecosystems Branch Chief, Manti-La Sal National Forest, Price, Utah; and to M. Nechodom, Research Social Scientist for the USDA Forest Service Pacific Southwest Research Station, Albany, California. Acknowledgement is also provided to P. Rundel, Professor of Botany, University of California, Los Angeles for input provided in various discussions regarding this paper. Finally, appreciation is extended to R. McCabe of the Wildlife Management Institute for editorial assistance, L. A. Walters at Cal Poly for clerical assistance, Dr. Sauli Valkonen and Mr. Gary Roller for assistance with metric conversions, and M. Correia of Slide People in Bakersfield California for graphic art work.

Developing and executing effective ecosystem management plans for giant sequoia groves requires input and work from a large number of concerned individuals. Working together we can make a difference.

\section{Literature Cited}

Anderson, M. A., R. C. Graham, G. J. Alyanakian, and D. Z. Martynn. 1995. Late summer water status of soils and weathered bedrock in a giant sequoia grove. Soil Science 160(6): 415-422.

Bonnicksen, T. M., and E. C. Stone. 1978. An analysis of vegetation management to restore the structure and function of presettlement giant sequoia-mixed conifer forest mosaics. Unpublished final report to the USDI National Park Service, Sequoia and Kings Canyon National Parks, CA.

Bonnicksen, T. M., and E. C. Stone. 1981. The giant sequoiamixed conifer forest community characterized through pattern analysis as a mosaic of aggregations. Forest Ecology and Management 3(1980/81):307-328,

Bonnicksen, T. M., and E. C. Stone. 1982a. Reconstruction of a presettlement giant sequoia-mixed conifer forest community using the aggregation approach. Ecology 63(4):11341148.

Bonnicksen T. M. and E. C. Stone. 1982b. Managing vegetation within U.S. national parks: a policy analysis. Environmental Management 6(2):101-102.

Bonnicksen, T. M. 1985. Restoring naturalness to national parks. Environmental Management 9(6):479-486.

Bonnicksen, T. M. 1988. Standards of naturalness: The national parks management challenge. Landscape Architecture $78(2): 134,120$

Bonnicksen, T. M. 1993a. Restoring ancient giant sequoia forests. An electronic publication. Department of Forest Science; College Station: Texas A\&M University.

Bonnicksen, T. M. 1993b. Ancient forests of the Sierra Nevada. Unpublished speaker's notes for an industry sponsored economic summit.
Bush G. 1992. Giant sequoia in national forests. A proclamation by the President of the United States. 1992 July 14; 1 p.

Caprio, A. C., L. S. Mutch, T. W. Swetnam, and C. H. Baisan. 1994. Temporal and spatial patterns of giant sequoia radial growth response to a high severity fire in A.D. 1297. Unpublished contract report to the California Department of Forestry and Fire Protection, Mountain Home State Forest.

Clinton, W. J. 2000. Presidential Proclamation-Establishment of the Giant Sequoia National Monument. April 15, 2000 .

Davidson, J. G. N. 1972. Pathological problems in redwood regeneration from seed. Berkeley: University of California; Ph.D. dissertation.

Demetry, A. and D. M. Duriscoe. 1996. Fire-caused canopy gaps as a model for the ecological restoration of giant forest village. Unpublished report to Sequoia and Kings Canyon National Parks, National Park Service, USDI.

Dunning, D. and H. Reineke. 1933. Preliminary yield tables for second-growth stands in the California region. USDA Forest Service, Pacific Southwest Forest and Range Experiment Station, Technical Bulletin No. 354. 24 pp.

Eaton, J. 1996. Personal communication. Retired District Fuels Specialist, Hot Springs Ranger District, Sequoia National Forest, Hot Springs, CA.

Fins. L. and W. J. Libby. 1982. Population variation in Sequoiadendron: Seed and seedling studies, vegetative propagation, and isozyme variation. Silvae Genetica 31(4):102-110.

Fins. L. and W. J. Libby. 1994. Genetics of giant sequoia. Pages 65-68 in P. Aune (technical coordinator). Proceedings of the symposium on giant sequoias: Their place in the ecosystem and society; 1992 June 23-25; Visalia, CA. Gen. Tech. Rep. PSW-GTR-151. Albany, CA: Pacific Southwest Research Station, Forest Service, U.S. Department of Agriculture; 65-68.

Fry, W. 1933. The giant sequoia avalanche. Sierra Club Bulletin 18:118-120.

Fry, W. and J. R. White. 1948. Big trees. Revised enlarged edition. Palo Alto: Stanford University Press; 126 pp.

Fullmer, D. G., R. R. Rogers, J. D. Manley, and L. L. Stephenson. 1996. Restoration as a component of ecosystem management for giant sequoia groves in California. Pages 109115 in D. L. Pearson, and C.V. Klimas (eds). Proceedings of the Society for Ecological Restoration conference, The role of restoration in ecosystem management; 1995 September 14-16; Seattle, WA. Society of Ecological Restoration, Madison, WI.

Guldin J. M. 1991. Uneven-aged Bdq regulation of Sierra Nevada conifers. Western Journal of Forestry 6(2):27-32.

Hammon, Jensen, and Wallen Mapping and Forestry Service. $1964,1970,1975$, 1976. Sequoia tree inventory. An unpublished report to the USDI National park Service, Sequoia and Kings Canyon National Parks.

Hartesveldt, R. J. and H. T. Harvey. 1967. The fire ecology of sequoia regeneration. Proceedings Tall Timbers Fire Ecological Conference 7:65-77.

Harvey, H. T., H. S. Shellhammer, and R. E. Stecker. 1980. Giant sequoia ecology, fire and reproduction. USDI Na- 
tional Park Service, Scientific Monograph Series No. 12. Washington, DC.

Holling C. S. 1992. Cross-scale morphology, geometry, and dynamics of ecosystems. Ecological Monographs 62(4):447502.

Huntington, E. 1914. The climatic factor as illustrated in arid America. The Carnegie Institute of Washington, Publication No. 192, Washington, DC.

Keifer, M. 1995. Changes in stand density, species composition, and fuel loading following prescribed fire in the southern Sierra Nevada mixed conifer type. Supplement to the Bulletin of the Ecological Society of America 76:138-139.

Kilgore, B. M. and D. Taylor. 1979. Fire history of a sequoiamixed conifer forest. Ecology 60(1):129-142.

Leuschner, W. A. 1984. Introduction to Forest Resource Management. New York: John Wiley and Sons, Inc.; 298 p.

McKelvey, K. S. and J. D. Johnston. 1992. Historical perspectives on forests of the Sierra Nevada and the Transverse Ranges of southern California: Forest conditions at the turn of the century. Pages 225-246 in J. Verner, K.S. McKelvey, B.R. Noon, R.J. Gutierrez, G.I. Gould Jr., and T.W. Beck (technical coordinators). The California spotted owl: A technical assessment of its current status. Gen. Tech. Rep. PSW-GTR-133. Berkeley, CA: Pacific Southwest Research Station, Forest Service, U.S. Department of Agriculture.

McKelvey, K. S., C. N. Skinner, C. Chang, D. C. Erman, S. Husari, D. J. Parsons, J. W. van Wagtendonk, and C. P. Weatherspoon. 1996. An overview of fire in the Sierra Nevada. In: Sierra Nevada Ecosystem Project: Final report to Congress, vol. II, chap. 37. Davis, CA: University of California, Centers for Water and Wildland Resources.

McKelvey, K. S. 1998. Personal communication.

Manley, P. N., G. E. Brogan, C. Cook, M. E. Flores, D. G. Fullmer, S. Husari, T. M. Jimenson, L. M. Lux, M. E. McCain, J. A. Rose, G. Schmitt, J. C. Schuyler, and M. Skinner. 1995. Sustaining Ecosystems-A Conceptual Framework. San Francisco, CA: USDA Forest Service Pacific Southwest Region. Report No. R5-EM-TP-001.

Muir, J. 1961. The mountains of California. Garden City, New York: Doubleday and Company; 300 p.

Patterson III, W. A. and I. C. Prentice. 1985. Quantitative interpretation of fossil pollen spectra: Dissimilarity coefficients and the method of modern analogs. Quarternary Research 23:87-108.

Piirto, D. D., R. R. Rogers, and M. C. Bethke. 1997. Communicating the role of science in managing giant sequoia groves. Pages 48-57 in D. Murphy and N. Loftus (technical coordinators). Proceedings of the National Silviculture Workshop; 1997 May 19-22; Warren, PA. Gen. Tech. Rep. GTR-NE-238. Radnor, PA: Northeastern Forest Experiment Station, Forest Service, U.S. Department of Agriculture.

Piirto, D. D. and R. R. Rogers. 1999a. Developing an ecological foundation for management of national forest giant sequoia ecosystems. Pages 246-274 in R. McCabe and S. Loos (eds.). Transactions of the Sixty-fourth North American Wildlife and Natural Resources Conference. Wildlife Management Institute, Washington DC.

Piirto, D. D. and R. R. Rogers. 1999b. An ecological foundation for management of national forest giant sequoia eco- systems. Berkeley, CA: USDA Forest Service Pacific Southwest Region, Sequoia National Forest, 900 West Grand Avenue, Porterville, CA. Technical Report R5-EM-TP-005. 105 p.

Piirto, D. D. 1977. Factors associated with tree failure of giant sequoia. Berkeley: University of California; 155 p. Ph.D. dissertation.

Rogers, Robert. 1997. Deer Creek Grove protection strategy. An unpublished report available from USDA Forest Service, Sequoia National Forest, 900 West Grand Avenue, Porterville, CA.

Rogers, R. R. 1998. An unpublished report of all known giant sequoia groves. Address inquiries to R. Rogers, c/o USDA Forest Service, Sequoia National Forest, Porterville, CA.

Rundel, P. W. 1971. Community structure and stability in the giant sequoia groves of the Sierra Nevada, California. The American Midland Naturalist 85(2):478-492.

Rundel, P. W. 1972a. An annotated list of the groves of Sequoiadendron giganteum in the Sierra Nevada-Pt. I. Madrono $21(5): 319-328$.

Rundel, P. W. 1972b. Habitat restriction in giant sequoia: the environmental control of grove boundaries. The American Midland Naturalist 87(1):81-99.

Shulman, D.; Gelobter, A. 1996. Evaluating potential loss from wildfire of specified forest and stand attributes on Sequoia National Forest. Unpublished draft report (dated 2/96) on file in the Porterville office of Sequoia National Forest.

Skinner, C. N.; Chang, C. 1996. Fire regimes, past and present. In: Sierra Nevada Ecosystem Project: Final report to Congress, vol. II, chap. 38. Davis, CA: University of California, Centers for Water and Wildland Resources.

Stephenson, N. L., D. J. Parsons, and T. W. Swetnam. 1991. Restoring natural fire to the sequoia-mixed conifer forest: Should intense fire play a role. Pages 321-337 in Proceedings of the 17th Tall Timbers Fire Ecology Conference, High Intensity fire in Wildlands: Management Challenges and Options; Tallahasse, FL. Tall Timbers Research Station.

Stephenson, N. L. 1987. Use of tree aggregations in forest ecology and management. Environmental Management 11(1): $1-5$.

Stephenson, N. L. 1994. Long-term dynamics of giant sequoia populations: Implications for managing a pioneer species. Gen. Tech. Rep. PSW-151. Forest Service, U.S. Department of Agriculture.

Stephenson, N. L. 1996. Ecology and management of giant sequoia groves. In: Sierra Nevada Ecosystem Project: Final report to Congress, vol. II, chap. 55. Davis: University of California, Centers for Water and Wildland Resources. 1431-1465.

Stephenson, N. L. 1998. Personal communication. Letter dated April 16.

Stohlgren, T. J. 1991. Size distributions and spatial patterns of giant sequoia in Sequoia and Kings Canyon National Parks. Davis: University of California; 300 p. Ph.D. dissertation.

Stohlgren, T. J. 1992. Resilience of a heavily logged grove of giant sequoia (Sequoiadendron giganteum) in Kings Canyon National Park, California. Forest Ecology and Management 54: 115-140.

Stohlgren, T. J. 1993a. Spatial patterns of giant sequoia (Se- 
quoiadendron giganteum) in two sequoia groves in Sequoia National Park, California. Canada Journal Forest Research 23: 120-132.

Stohlgren, T. J. 1993b. Intraspecific competition (crowding) of giant sequoias (Sequoiadendron giganteum). Forest Ecology and Management 59:127-148.

Swetnam, T. W., C. H. Baisan, A. C. Caprio, R. Touchan, and P. M. Brown. 1992. Tree-ring reconstruction of giant sequoia fire regimes. Unpublished final report to Sequoia, Kings Canyon and Yosemite National Parks. Cooperative Agreement No. DOI 8018-1-0002. Tueson: University of Arizona, Laboratory of Tree Ring Research.

Swetnam, T. W. 1993. Fire history and climate change in giant sequoia groves. Science 262:885-889.

Thomas, J. W. 1993. Forest management approaches on the public lands. Albright Lecturer speech. University of California, Berkeley.

Tweed, W. 1994. Public perception of giant sequoia over time. Pages 5-7 in Aune, P.S. (technical coordinator), Proceedings of the symposium on giant sequoias: Their place in the ecosystem and society; 1992 June 23-25; Visalia, CA. Gen. Tech. Rep. PSW-GTR-151. Albany, CA: Pacific Southwest Research Station, Forest Service, U.S. Department of Agriculture.
University of California, Centers for Water and Wildland Resources. 1996. Sierra Nevada ecosystem project, final report to Congress, vol. I, assessment summaries and management strategies. Davis: University of California, Centers for Water and Wildland Resources.

USDA Forest Service. 1990. Sequoia National Forest Mediated Settlement Agreement. Unpublished administrative document, Porterville, CA.

USDA Forest Service. 1993. California spotted owl Sierran Province interim guidelines environmental assessment. Pacific Southwest region, San Francisco, CA.

USDA Forest Service. 1996. Grant sequoia memorandum of understanding (MOU) for the giant sequoia ecology cooperative. Copies of the MOU agreement can be obtained from the USDA Forest Service, Sequoia National Forest, 900 West Grand Avenue, Porterville, CA.

Verner, Jared. 1998. Personal Communication.

Western Timber Service. 1970. Sequoia tree inventory. An unpublished report to the USDI National Park Service, Sequoia and Kings Canyon National Parks.

Willard, D. 1995. Giant sequoia groves of the Sierra Nevada, a reference guide. Self published. Address inquiries to D. Willard, P.O. Box 7304, Berkeley, CA 94707. 